\title{
Decolonizing the Shopping Mall: A Reading of Spaces within the United Arab Emirates
}

\author{
Salem AISuwaidi ${ }^{1}$ and Felipe Botelho Correa\# \\ ${ }^{1}$ Kings College London, UK \\ \#Advisor
}

ABSTRACT

Does it make sense to speak of a 'reading' of space? If so, what implication does that have on our experience of said space once a reading is complete and to what extent would this reading hinder or strengthen the individual or community? A reading of space has become a crucial tool in global affairs and multinational internet culture. Such a tool would allow for critiquing and dissecting unidentifiable power relations within spaces then redirecting the social production of identity and hegemony. One such discourse can be of Western cultural hegemony. This paper will begin by defining the theoretical framework that will then be used to illustrate and analyze a given space. The space chosen will be shopping malls in the United Arab Emirates, specifically their food courts and restaurants, as this nation is situated geographically in a non-Western region. A Content Analaysis of the websites of the malls selected in the capital, Abu Dhabi, will illustrate the physical literal construction of this space. An analysis of these theories and illustrations about the space will aid in a debate on shopping mall restaurants' implications on identity and Western cultural hegemony. It will be concluded that a reading of space is a crucial tool to demystify the reality of Western influence on Eastern social and cultural development and ultimately critiquing the production of such spaces in order to decolonize the region.

\section{Theoretical Framework: Conceptualizing Space and Place}

To begin, understanding the purpose of 'reading a space' will help in approaching a defining critical analysis of the space of shopping mall restaurants, cafes, and food courts. Henri Lefebvre introduces the philosophy of Hegelianism production where "first, the Idea produces the world; next, nature produces the human being; and the human being in turn [produces] history, knowledge and self-consciousness" (Lefebvre, 2011, pp.68). Spatial production results are products that "can be reproduced exactly" (Lefebvre, 2011, pp.70). Therefore, Malls are social spaces where knowledge and culture are met by the conscious mind, producing interactions that can then translate into defining political identities, repeatedly. Lefebvre then begins to introduce the idea of social spaces that 'interpenetrate' and 'superimpose,' meaning "each fragment of space subjected to analysis" reveals a host of social relationships (Lefebvre, 2011, pp.88). This identifies the need for a 'reading of space.' Lefebvre would argue that the lack of such criticism merely exists because an exact picture of such readings "would differ considerably from the one embodied in the representational space which its inhabitants have in their minds" and would essentially obstruct social practice (Lefebvre, 2011, pp.93). By conceptualizing a space that is considered mundane and 'natural,' when humans deliberately construct it, certain difficult power relations begin to reveal themselves, specifically those imposed by post-colonial Western cultural hegemony.

Marc Augé further explores the conceptualization of space by introducing the ideas of place and non-place, which aid in reading and criticizing Lefebvre's social spaces. Augé relies on Michel de Certeau's works, who suggested that space can be understood as "a frequented place, an intersection of moving bodies," and it is these bodies that define such a space (Conley, 2012, pp.79). This introduces the binary ideas of place and non-place to define a 
space further. 'Place' would be defined as "relational, historical and concerned with identity" while a non-place would lack these elements (Conley, 2012, pp.77). A 'non-place' would, therefore, "creates solitary contractility" while "anthropological places create the organically social" (Conley, 2012, pp.94). Here, the organic carries meaningful activity associated with the production of a place that allows agency and authenticity while the non-place creates a systematic order, which Augé would associate with the idea of 'supermodernity.' A mall, for instance, would be an example of a non-place. In Augé's argument, "the user of non-place is in contractual relations with it (or with the powers that govern it)," illustrating that all identity and agency is lost to some governing power identifiable and labeled by imposed texts and orders of institutions (Conley, 2012, pp.101). Supermodernity, therefore, is a concept of a clash between the old and the new. This clash is observable in the colonial settings of modern shopping malls and food courts in regions such as the Gulf, consisting of relatively young and impressionable nations that were previously territories of Western empires.

\section{Illustration of the Selected Space: Shopping Mall Restaurants in the UAE}

What value, however, does the selection of malls have in the discourse of the reading of spaces? Rana AlMutawa would interpret "malls as important sites for belonging and socializing and interrogate how exclusions shape that sense of belonging," as users of malls in the UAE explicitly utilize such spaces to 'show their faces' (AlMutawa, 2020, pp.47). This aligns with René Grotenhuis's perceptive on national identity as something that is not replaceable by globalization. In such a "confusing world, where people have lost their sense of belonging and identification," the relevance of forming tangible identities becomes a greater desire (Grotenhuis, 2016, pp.126). In AlMutawa's work, she highlights an example of Emiratis (citizens of the UAE) "turning a coffee shop into a milas [or majlis, meaning a communal living space]... entering a busy café and calling out... "al-salam 'alaykum [meaning 'Hello'] as they enter Emirati-dominated coffee shops" (AlMutawa, 2020, pp.59). However, to what extent is this experience relevant to, for example, expatriates within the UAE, and do these effects wear off altogether in larger spaces with a vast plethora of extensively Western restaurants, such as places like the shopping mall? Here it is evident that such a space has merit when attempting to critique identity and global hegemony in the current neoliberal climate.

To first illustrate the space explored—restaurants and food courts within malls in Abu Dhabi-a Content Analysis of the malls must be conducted, which is typically 'objective' and 'systematic,' allowing for 'transparency' (Bryman, 2012, pp.289). The data will be collected by visiting the host websites of the top five most popular malls in the capital of the United Arab Emirates, Abu Dhabi, and collecting information from these host websites on the dining options at their malls. The raw material (Table 1) produced through Content Analysis is then presented with a tool called a Codebook, which composed of a coding manual (Table 2) and schedule (Table 3). The process consists of categorization and interpretation by creating columns and rows, tracking certain variables, and comparing the research subjects. One advantage to creating codebooks is that these procedures are "clearly set out so that replications and follow-up studies are feasible"; however, "coders must draw upon their everyday knowledge," which entails a degree of bias when it comes to categorizing what is being tracked (Bryman, 2012 pp.304-306). Nonetheless, this process allows for data organization into a coding schedule that will aid in reading and analysis of the space.

The most dominant and repetitive trends observed amongst each of the top five malls in this data are Column C's (Table 3) results, the 'Percentage of Restaurants that are of Western Cuisine,' and Column D (Table 3), the 'Percentage of Restaurants that are Regional/Eastern.' Around 50-75\% of every single mall's restaurants and cafes are of Western cuisine. The younger, newer malls tend to have more restaurants, ultimately a higher percentage of them ending up being categorized as Western, serving food originating and popular in those regions geographically. Additionally, Regional/Eastern cuisine restaurants and cafes make up less than $50 \%$ of the options at all these malls. The overwhelming majority is consistently Western. On top of that, of these geographical Western cuisine restaurants, at every single mall, American and British chain corporations are the hegemony of these outlets, with Al Wahda Mall having over $75 \%$ of its Western restaurants come from an American/British chain. This would include anything from McDonald's and KFC to Chili's and Red Lobster. 


\section{Implications of Restaurants in Malls on National Identity}

To elaborate on the effects of the mall and food courts on identity, 'influence' must be assessed, a staple characteristic of defining power. Western civilization is shaped by consumerism, living in its "culture, its norms, and its values... honoring mass consumption," which attaches the user of spaces like malls to 'modernity' and capitalism (Spilková and Radová, 2011, pp.568). When conceptualizing the culture of teenagers and malls, Jana Spilková and Lucie Radová build on the ideas of Miloslav Petrusek and argue that "media and publicity exercise an influence on people's minds, telling the consumers what to do, buy, consume, and how to behave," suggesting humans are essentially 'manipulated' and 'seduced' by this mall micro-culture (Spilková and Radová, 2011, pp.568). Here, the authors specifically refer to fashion and consumer goods that reflect on their activities, but as indicated through the data, the overhaul of American and British food chain restaurants may play a role in shaping this consumer fetishization culture. The desire to fit into the West's lifestyles captured on the television screen and in the news-associated with their booming economy, global power, and cultural legacies_-is experienced when exploring modern malls' food courts. As newer malls open up, more restaurants are of American cuisine, exactly mimicking the spaces of the West. In fact, when reading Columns $\mathrm{A}$ and $\mathrm{F}$ of Table 3, these younger malls then become more poplar than older malls, meaning they are ideally more profitable.

Furthermore, James Ferguson would even go as far as to suggest this pursuit of Western cultural norms, their hegemony over the concept of a global identity, is a result of colonialism. Ferguson argues that consumer choices are not merely cultural practices but also "yearnings for cultural convergence with an imagined global standard," illustrating a form of "mental colonization... cultural imperialism [and] an aspiration to overcome categorical subordination" (Ferguson, 2006, pp.20). Holding onto cultural differences may be seen as social and economic subjection rather than cultural resistance to globalization. This has "brought an increasingly acute awareness of the material goods of the global rich," which are then "likely to be celebrated by the cultural analyst" (Ferguson, 2006, pp.21). These analysts then influence the global political discourse of modernity and development, critiquing those nations that have not adopted the materialist, Western culture of capitalism and consumption while celebrating those who have subjected themselves to 'modernization.' Rather than investing in home grown or regional restaurants, the malls of Abu Dhabi, as seen through the data, will almost always opt for having a majority Western centric dining option, under the illusion that this will establish them as renowned malls and exclusively modern. This reading reveals that there must be some revision done to the current discourse of modernity in order to limit Western influence on social development that may evoke practices of sacrificing economic and cultural resources.

\section{Implications of Restaurants in Malls on the Discourse of Westem Hegemony}

\section{A. Counter-Argument: The Dangers of a Reading of Space}

In opposition, the reading of space may rather exploit biased understandings that may ultimately put in danger the values formed through natural works of humanity. Some readings gear towards recommending conformity through 'Western' progress when it focuses on urban and social development. The West and Rest's discourse is crucial to an analysis of such a space when analyzing the implications of a reading of restaurants in malls. Stuart Hall claims, “The West' is as much an idea as a fact of geography," with the meaning of the word evolving into merely signaling modernity and an elite status (Hall, 2019, pp.142). He further illustrates that such a discourse "allows us to characterize and classify societies into different categories... [creates] an image... a standard for comparison... and provides criteria of evaluation against which other societies are ranked" (Hall, 2019, pp.143). Essentially, Hall reveals that this discourse has established that 'Western' $=$ urban $=$ developed $=$ good, and 'non-Western' $=$ nonindustrial $=$ rural $=$ agricultural $=$ underdeveloped $=$ bad. This reading favors the colonizers of the past and stigmatizes the inhibitors of the Global South. It creates powerful changes to certain nation-states' identities and ultimately 'Westernizing' the 
people and economy within those states. Therefore, when using this discourse to strategize developing Western places in the East, a reading of space may not be sympathetic and would be considered nonsensical for the harmful manipulation by political figures and economic investors.

Furthermore, Donald Moore explores how hegemonic discourse becomes entangled in people's cultural practices and social relations in certain places. He suggests that the production of place entails the emergence of a "distinctive picture... a nodal point where these trans local influences intermesh with practices and meanings previously sedimented in the local landscape" (Moore, 2005, pp.20). This is how Western cultural hegemony becomes engulfed with the social construction of spaces in regions such as the Middle East, specifically through the spaces of interaction, engagement, and cross-cultural entanglement at food courts within malls. Moore is very critical of this exchange as he acknowledges that the "axes of inequality, differences of identity, and power relations" are evident within these places; there is no 'unitary' experience, and "within any one place, social actors become subjected to multiple matrices of power" (Moore, 2005, pp.21). An interpretation of this analysis can be used as a critique of Augé's Eurocentric ideas of non-place and his lack of considering the power relations of identity politics that may play a role in a place's social production.

Although all users of such places may undergo the supervision of a systematic, structural non-place, governed by regulations, expectations, and texts, not all individuals — due to race, gender, socio-economic class, and religionwill have similar implications to that of the White man on their experience of said place. For example, with mall food courts, although the systematic process of queuing up at a restaurant, staring at the menu, selecting options, placing an order and paying, consuming an order, and leaving may be repetitive and identical, the pressurization of Western culture on non-Western users is consistent throughout the mall as it overhauls the options of regional choices. This seduces the individual to pursue the most popularized option and forgo the value of their culture in mere pursuit of a glimpse of American exceptionalism present in the neoliberal, free-market choices of fast-food chain restaurants. This is the internal social obstruction Lefebvre was hinting at as a consequence of a reading of space that deters criticisms of social places as it is a confrontation of weakness. This reading and analysis, therefore, work as a capitalist tool in future development projects regionally. Western culture can localize itself, almost as a form of propaganda for Western modernity, as newer malls in Abu Dhabi begin opening drastically more American and British restaurants.

\section{B. The Contrary Benefits to Re-Reading Space}

However, these observations of the analysis's consequential nature are one Lefebvre initially realized, and suggests can be utilized to overcome institutionalized hegemonic power through a re-reading. This analysis, as mentioned, allows a realization of the weakening of the Middle Eastern and Asian identity in favor of a profitable American culture. Michel Foucault suggested "another way to go further toward a new economy of power relations consists of using resistance as a chemical catalyst so as to bring to light power relations... positions [and] methods" (Foucault, 780). In Foucault's point of view, discourse defines power, and all these forms of resistance to authority have certain commonalities. Some of these include the fact that they are "transversal struggles... which question the status of the individual [and] are an opposition to the effects of power which are linked with knowledge, competence and qualifications," revolving around the idea and pursuit of identity (Foucault, 781). Therefore, discourse is a form of immediate everyday power that subjects individuals, either to the control of someone else or themselves.

Ultimately, Foucault is critiquing not the institutions that inherit these powers but the strategy of formulating such power. Identity is met with "three types of struggles: working against forms of domination (ethnic, social and religious); against forms of exploitation... or against subjection, subjectivity, and submission" (Foucault, 781). A reading of space allows for a challenge to the West vs. Rest discourse and a rejection of modernity in favor of postmodern and post-structural identity formation ideas. Awareness of such practices, and a study of them through political theory, can allow for pursuing urban development and social policies that operate through non-Western mechanisms. This means focusing on increasing the percentage of Regional/Eastern cuisine restaurants, for example, in the malls studied earlier. The capitalist, Western consumer culture can be dismantled and provide an opportunity to enrich local 
businesses, fair trade operations, and multicultural Eastern options. What this ensures is the separation from a dependency on Western ideals and influence on the direction of progress and market operations. It will also create more extensive dynamics between these spaces' users as more socio-economic and ethnic classes can begin sharing a place rather than having a dominating, intrusive force. This will provide the individual with a holistic approach to identity development, both culturally and socially, and limit the degree of potentially propaganda-esque American/British ideologies found in popular consumer culture.

\section{Conclusion}

In summation, through an investigation of shopping malls in the UAE, specifically the places of dining, it is evident that a reading of space is crucial to identify the power dynamics within such a space. With an overhaul of American and British chains, Western cultural hegemony prevails as the dominant form of modernity and progress. However, as developed through the argument, it begins to weaken the identities of nation-states of the Global South and helps Western colonial hegemony over economics, development, and social culture prevail. Although capitalists may use it to manipulate and exploit consumers, a reading of space can ultimately help decolonize the current and future construction of social spaces. This decolonization will allow for the post-modern identities of states like the UAE to establish their global presence without the shadow of Western hegemony and influence continually lurking.

\section{Appendix}

Table 1: Data Collected on the Top 5 Most Popular Malls in Abu Dhabi through Information from Host Websites

\begin{tabular}{|l|l|l|l|l|l|l|l|l|l|}
\hline $\begin{array}{l}\text { Mall } \\
\text { Name }\end{array}$ & $\begin{array}{l}\text { \# of } \\
\text { Google } \\
\text { Reviews }\end{array}$ & $\begin{array}{l}\text { \# of } \\
\text { Restaura } \\
\text { nts }\end{array}$ & $\begin{array}{l}\text { \# of } \\
\text { Western } \\
\text { Restaura } \\
\text { nts }\end{array}$ & $\begin{array}{l}\text { \% of } \\
\text { Restaura } \\
\text { nts that } \\
\text { are } \\
\text { Western }\end{array}$ & $\begin{array}{l}\text { \# of } \\
\text { Regional } \\
\text { /Eatern } \\
\text { Restaura } \\
\text { nts }\end{array}$ & $\begin{array}{l}\text { \% of } \\
\text { Restaura } \\
\text { nts that } \\
\text { are } \\
\text { Regional } \\
\text { /Eastern }\end{array}$ & $\begin{array}{l}\text { \# of } \\
\text { America } \\
\text { n/British } \\
\text { Chains }\end{array}$ & $\begin{array}{l}\text { \% of } \\
\text { America } \\
\text { n/British } \\
\text { Chains }\end{array}$ & $\begin{array}{l}\text { Age of } \\
\text { Mall }\end{array}$ \\
\hline Yas Mall & 25,641 & 67 & 41 & 0.61 & 26 & 0.39 & 30 & 0.73 & 7 \\
\hline $\begin{array}{l}\text { Dalma } \\
\text { Mall }\end{array}$ & 21,874 & 63 & 33 & 0.52 & 30 & 0.48 & 24 & 0.73 & 11 \\
\hline $\begin{array}{l}\text { Al } \\
\text { Wahda } \\
\text { Mall }\end{array}$ & 20,837 & 50 & 31 & 0.62 & 19 & 0.38 & 24 & 0.77 & 14 \\
\hline $\begin{array}{l}\text { Marina } \\
\text { Mall }\end{array}$ & 21,600 & 55 & 33 & 0.6 & 22 & 0.4 & 20 & 0.61 & 20 \\
\hline $\begin{array}{l}\text { Abu } \\
\text { Dhabi } \\
\text { Mall }\end{array}$ & 15,931 & 47 & 32 & 0.68 & 15 & 0.32 & 18 & 0.56 & 20 \\
\hline
\end{tabular}


Table 2: Coding Manual: method by which data is categorized

\begin{tabular}{|c|c|c|}
\hline $\begin{array}{l}\text { A. Number of Reviews on Google } \\
\begin{array}{l}\text { 1. Around } 15,000 \\
\text { 2. Around } 20,000 \\
\text { 3. Around } 25,000\end{array}\end{array}$ & $\begin{array}{l}\text { B. Total Number of Restaurants } \\
\begin{array}{l}\text { 1. } 40-49 \\
\text { 2. } 50-59 \\
\text { 3. } 60-69\end{array}\end{array}$ & $\begin{array}{l}\text { C. Percentage of Restaurants that } \\
\text { are of Western Cuisine } \\
\begin{aligned} \text { 1. } & <50 \% \\
\text { 2. } & 50-75 \% \\
\text { 3. } & >75 \%\end{aligned}\end{array}$ \\
\hline $\begin{array}{l}\text { D. Percentage of Restaurants that } \\
\text { are Regional/Eastern } \\
\begin{aligned} \text { 1. } & <50 \% \\
\text { 2. } & 50-75 \% \\
\text { 3. } & >75 \%\end{aligned}\end{array}$ & $\begin{array}{l}\text { E. Percentage of Western } \\
\text { Restaurants that are } \\
\text { American/British Chains } \\
\text { 1. } \quad<50 \% \\
\text { 2. } 50-75 \% \\
\text { 3. }>75 \%\end{array}$ & $\begin{array}{l}\text { F. Age of Mall (Years) } \\
\begin{array}{ll}\text { 1. } & 5-10 \\
\text { 2. } & 10-15 \\
\text { 3. } & 15-20\end{array}\end{array}$ \\
\hline
\end{tabular}

Table 3: Coding Schedule: a set of codes, defined by the categories used to segment the data by topic

\begin{tabular}{|c|c|c|c|c|c|c|c|c|}
\hline Case \# & $\begin{array}{l}\text { Name of } \\
\text { Mall }\end{array}$ & Date & $\mathbf{A}$ & B & C & D & $\mathbf{E}$ & $\mathbf{F}$ \\
\hline 1 & Yas Mall & $\begin{array}{l}4 \text { January } \\
2021\end{array}$ & 3 & 3 & 2 & 1 & 2 & 1 \\
\hline 2 & $\begin{array}{l}\text { Dalma } \\
\text { Mall }\end{array}$ & $\begin{array}{l}4 \text { January } \\
2021\end{array}$ & 2 & 3 & 2 & 1 & 2 & 2 \\
\hline 3 & $\begin{array}{l}\text { Al Wahda } \\
\text { Mall }\end{array}$ & $\begin{array}{l}4 \text { January } \\
2021\end{array}$ & 2 & 2 & 2 & 1 & 3 & 2 \\
\hline 4 & $\begin{array}{l}\text { Marina } \\
\text { Mall }\end{array}$ & $\begin{array}{l}4 \text { January } \\
2021\end{array}$ & 2 & 2 & 2 & 1 & 2 & 3 \\
\hline 5 & $\begin{array}{l}\text { Abu } \\
\text { Dhabi } \\
\text { Mall }\end{array}$ & $\begin{array}{l}4 \text { January } \\
2021\end{array}$ & 1 & 1 & 2 & 1 & 2 & 3 \\
\hline
\end{tabular}

\section{References}

AlMutawa, R.(2020). ““'Glitzy” Malls and Coffee Shops: Everyday Places of Belonging and Social Contestation in Dubai," Arab Studies Journal, Vol. XXVIII, No. 2.

Bryman, A. (2012). “Content Analysis.”(chapter 13) in Social Research Methods. Oxford:Oxford University Press. 
Conley, V. (2012). Spatial Ecologies: Urban Sites, State and World-Space in French Cultural Theory. Liverpool University Press. Retrieved January 9, 2021, from http://www.jstor.org/stable/j.ctt5vjc34

Ferguson, J. (2006). Global Shadows: Africa in the Neoliberal World Order. Durham; London: Duke University Press.

doi:10.2307/j.ctv11g97mg

Foucault, M. (1982). The Subject and Power. Critical Inquiry, 8(4), 777-795. Retrieved January 9, 2021, from http://www.jstor.org/stable/1343197

Grotenhuis, R. (2016). National identity: A model and its content. In Nation-Building as Necessary Effort in Fragile States (pp. 125-152). Amsterdam: Amsterdam University Press. doi:10.2307/j.ctt1gr7d8r.12

Hall, S. (2019). Essential Essays, Volume 2: Identity and Diaspora (Morley D., Ed.). DURHAM; LONDON: Duke University Press. doi:10.2307/j.ctv11smnnj

Lefebvre, H. (2011). The Production of Space (D. Nicholson-Smith, Trans.). Malden, Mass.: Blackwell.

Moore, D.S. (2005). Suffering for territory: race, place, and power in Zimbabwe, Duke University Press. doi:10.1215/9780822387329

Spilková, J., \& Radová, L. (2011). The Formation of Identity in Teenage Mall Microculture: A Case Study of Teenagers in Czech Malls. Sociologický Časopis / Czech Sociological Review, 47(3), 565-586. Retrieved January 9, 2021, from http://www.jstor.org/stable/23073267

\section{Codebook Source:}

Abu Dhabi Mall. (n.d.). Retrieved January 4, 2021, from http://www.abudhabi-mall.com/

Al Wahda Mall. (n.d.). Retrieved January 4, 2021, from https://alwahda-mall.com/

Dalma Mall. (n.d.). Retrieved January 4, 2021, from https://www.dalmamall.ae/

Marina Mall. (n.d.). Retrieved January 4, 2021, from http://www.marinamall.ae/

Yas Mall. (n.d.). Retrieved January 4, 2021, from https://www.yasmall.ae/en/home 